Boise State University

ScholarWorks

Public Policy and Administration Faculty

Publications and Presentations

$3-2020$

Merit, Diversity, and Performance: Does Diversity Management

Moderate the Effect of Merit Principles on Governmental

Performance?

\author{
Sanghee Park \\ Boise State University \\ Jiaqi Liang \\ University of Illinois at Chicago
}

Park, S. \& Liang, J. "Merit, Diversity, and Performance: Does Diversity Management Moderate the Effect of Merit Principles on Governmental Performance?", Public Personnel Management, 49(1), pp. 83-110. Copyright (C) 2020, SAGE. Reprinted by permission of SAGE Publications. Doi: 10.1177/0091026019848459 


\title{
Merit, Diversity, and Performance: Does Diversity Management Moderate the Effect of Merit Principles on Governmental Performance?
}

\author{
Sanghee Park \\ Boise State University \\ sangheepark@boisestate.edu
}

\author{
Jiaqi Liang \\ The University of Illinois at Chicago \\ liangj@uic.edu
}

Accepted for Publication at Public Personnel Management

\begin{abstract}
The compatibility of merit principles and diversity management is particularly intriguing in theory and practice. Although theoretical arguments for merit-based practices and diversity management are well established, the effect of their dynamics on governmental performance remains an empirical issue. This article examines the effect of merit principles, workforce diversity, and diversity management on government performance, and inquiries about whether diversity management efforts moderate the effect of merit-based practices. Analyzing a combined dataset on federal agencies, this study finds that merit-based practices and diversity management have independent positive impact on organizational performance, but there is no significant relationship between workforce diversity and performance. Furthermore, the effect of merit-based practices on organizational performance is moderated by gender diversity and diversity management. Specifically, if an agency has a more diverse workforce in terms of gender or more effective diversity management efforts, the positive effect of merit-based practices on organizational performance is strengthened.
\end{abstract}

\section{Introduction}

Merit principles and diversity management undoubtedly are two of the most important managerial policies in the contemporary public sector. Merit-based practices and diversity management have been developed through different historical contexts with distinct managerial emphases. Merit principles have long served as a guiding value in public personnel management since the enactment of the Pendleton Act of 1883 and been reinforced by the Civil Service Reform Act of 1978 (CSRA). Merit principles have been powerful in replacing aristocracy, neutralizing the political system, and strengthening professionalism of the public bureaucracy (Groeneveld and Van de Walle 2010). Institutions that stem from merit principles epitomized by competitive hiring, protected tenure, and political neutrality constitute a core foundation of American civil service (Ruhil and Camoes 2003).

An increasingly diverse workforce in the public sector, however, has posed new challenges to public personnel management (Selden and Selden 2001; Riccucci 2002). Scholars, practitioners, and policymakers have raised concerns about the compatibility of merit principles with policies and programs that focus on promoting demographic diversity (McCrudden 1998; Woodard 2005). Affirmative action policies, for example, have been adopted in various areas, such as legislatures, universities, and corporate boards, to promote diversity and achieve restorative justice. On one hand, however, it has long been contested that affirmative action runs counter to meritocracy as the former offers advantages to certain subpopulations based on ascribed characteristics (e.g., gender, race), but not on earned qualifications. On the other hand, it has been argued that affirmative action policies can enhance meritocracy by allowing for fair and equal opportunity to the historically disadvantaged. As such, the compatibility of merit principles and diversity management, two key human resource management institutions in the public sector, is particularly intriguing in theory and practice. Although theoretical arguments for merit-based practices and diversity management have been well established, the effect of their dynamics on governmental performance remains an empirical issue.

This article examines the effect of merit principles, workforce diversity, and diversity management on federal agencies' performance, and inquiries about the extent to which workforce diversity and diversity management efforts moderate the effect of merit-based practices. Specifically, this study partials out the effect of diversity on 
organizational performance by distinguishing workforce diversity and management efforts for diversity. We argue that merit-based practices and diversity management are not contradictory but rather complementary, and have a conditional relationship for governmental performance. In our analysis, workforce diversity represents the degree of demographic composition in terms of gender and race, while diversity management refers to "a general set of human resource policies aimed at making workplaces more tolerant and inclusive of people from historically underrepresented groups, such as racial minorities and women” (Oberfield 2014: 778).

In the following sections, we first review the literature on merit principles, workforce diversity, and diversity management, and then develop three sets of hypotheses on the relationship between merit principles, workforce diversity, diversity management, and government performance. The description of data, measures, and analytic method are followed. We then present and discuss our results and conclude with implications.

\section{Theory and Hypotheses}

\section{$\underline{\text { Merit Principles and Governmental Performance }}$}

Merit principles "are designed to protect career employees against improper political influences or personal favoritism in the recruiting, hiring, promotion, or dismissal processes, to assure that personnel management is conducted without discrimination” (S. REP. No. 969, supra note 13, at 18; recited from O'Rourke 1993: 344). Established by the Pendleton Act, the merit system in civil service was developed as a political and administrative response to detriments of patronage and spoils systems and based on three principles: "entry to the system by way of competitive examination, promotion and penalty based on performance, and protection from actions based on partisan political pressure" (Pfiffner 2000: 27-28). Accordingly, the primary purpose of merit principles in early times was to eliminate political corruption based on partisanship.

Although merit remains as an underlying principle for human resource management in the public sector, its specific meaning has been evolving and reinterpreted in different ways, especially since the 2000s (Woodard 1998, 2005; McCrudden 1995). More specifically, during the foundational era of civil service since 1883 through the 1950s, personnel administration/management put an emphasis on efficiency and neutral competence through rule compliance and administrative control. During the 1960s through the 1990s, the meaning of merit changed from one-size-fits-all personnel management to human resource management that focused on social concerns related to fairness and equity. Since the 2000s, the concept of merit has been associated with more negative connotations, as a merit-based institution has been regarded as "a system of centralized regulation and compliance" (Woodard 2005, 110). Although fairness and equity are part of the core values of merit principles (i.e., 5 U.S.C. 2301 (b): the second Merit System Principle Fair and Equitable Treatment), the contemporary focuses of human capital management are managerial flexibility to meet specific needs of individual agencies and democratic values within the legal context of civil rights and employment law (for details about the historical evolution of the merit concept, see Woodard 2005).

Previous research has noted the potential negative impact of merit-based hiring, e.g., rigidity and inflexibility (Maranto 1998; Ingraham, Selden, and Moynihan 2000; Woodard 2005). This line of research argues that hiring policies that deviate from traditional merit criteria do not necessarily lead to a low level of government performance (Johnson 2015); instead, they may help promote high-quality service by creating a more malleable and receptive administration with increased managerial authority, discretion, and flexibility (Maranto 1998; Green et al. 2006; Kellough and Nigro 2006; Krause, Lewis, and Douglas 2006; Ogrysko 2016). Maranto (1998) argues that the regular rotation of political appointees helps expose public corruption, which runs counter to the perception that a spoils system brings more corruption. Merit principles may prevent public employees "from being creative and innovative from time to time" (Ogrysko 2016, an interview with Kevin Mahoney, the Chief Human Capital Officer in the U.S. Department of Commerce).

Furthermore, insulation from politics may not always be in accord with modern managerial strategies that also aim at enhancing administrative responsiveness and democratic accountability. As Ingraham (2006) suggested, it appears to be unrealistic and politically indefensible for public administrators not to engage with key external stakeholders (e.g., elected officials and citizens), as it eventually is harmful to government's effectiveness. Despite the consistence of the Wilsonian separation of politics and administration with the concept of a merit-based civil service, "[a] key objective of the CSRA, however, was to break down the barriers to responsiveness, cooperation, and coordination between career managers and political appointees that had resulted in a 'government of strangers”” (Brook 2000: 7). 
This is an author-produced, peer-reviewed version of this article. The final, definitive version of this document can be found online at Public Personnel Management, published by SAGE. Copyright restrictions may apply. doi: 10.1177/0091026019848459

Nevertheless, since the 1990s, there is a long line of research offering strong evidence on the positive impact of adherence to merit principles or the negative impact of violation of such practices (Kranz 1974; Huselid 1995; Gilmour and Lewis 2006; Lewis 2008a, 2013). For example, Lewis (2013) finds that hiring based on the veteran status, not on traditional merit criteria, may harm the quality of the federal public service. As Kettl (2015) noted, protecting civil service employees against political abuse and ruling out at-will employment are an essential part of merit principles and professionalism in government. In addition, as a modern application of merit principles, the idea of linking pay to performance has been a popular strategy of public personnel management to enhance government performance and flexibility, although the connection between pay-for-performance and government performance is rather unclear (Brook 2000; Gerrish 2016; McCrudden 1998; Kellough and Lu 1993; Pearce and Perry 1983; Weibel, Rost, and Osterloh 2010).

Given the consistent empirical evidence on the positive impact of merit-based practices, our first hypothesis is stated as follows:

H1: Organizational compliance with merit principles is positively related to governmental performance.

Workforce Diversity, Diversity Management, and Governmental Performance

This section identifies two additional hypotheses pertaining to the relationship of workforce diversity and diversity management with government performance, considering the conceptual distinctiveness between diversity and diversity management. For starters, workforce diversity refers to "the extent to which a group is composed of individuals who are similar on relevant dimensions, whether based on observable or unobservable attributes", and relevant dimensions include occupational, professional, and social (Pitts and Towne 2015: 368). Social diversity, which has been an important research focus in the public management literature, encompasses race and ethnicity, gender, sexual orientation, religion, language, and other cultural backgrounds. Given the increasingly diverse workforce in the public sector, the theory of representative bureaucracy offers a foundation for the exploration of how the demographic compositions of public organizations can shape equal access to decision making and equal opportunity of employment for women and minorities. Pitkin (1967) suggests that representation enhances the value of responsiveness in government as descriptive representation ("standing for") leads to active representation ("act for" the constituents they represent).

However, empirical evidence is inconclusive as to whether employee diversity is related to better government performance (Andrews, Boyne, Meier, O’Toole, and Walker 2005; Choi 2009; Jehn, Northcraft, and Neale 1999; Naff and Kellough 2003; Pitts 2005, 2009; Tsui, Egan, and O’Reilly 1992; Watson, Kumar, and Michaelson 1993). Theoretically, two sets of competing driving forces are in play for the possible effect of employee diversity on organizational effectiveness (Pitts and Towne 2015). On one hand, the theory on decision making suggests that potential benefits from a diverse workforce (or a more representative workforce) are linked to the synergetic effect of more talents, broader knowledge, new perspectives and ideas, as well as creativeness and innovation (Mosher 1968; Ospina 2001; Anderson and Moynihan 2016). Also, diversity promotes social and political legitimacy as well as normative values, such as fairness, justice, equal opportunity, and democracy (McCrudden 1998).

On the other hand, the theory on social categorization and similarity-attraction posits that "breakdowns in communication, coordination, and cohesion" in diverse organizations results from a low level of mutual trust and less confidence in peers' capacities due to grouping and categorization (i.e., in-groups vs. out-groups) (Pitts and Towne 2015: 369; Williams and O’Reilly 1998). In this case, organizational diversity may weaken stability, engender conflicts among members, maximize the feeling of exclusion and discrimination, and eventually undermines the performance and legitimacy of an organization (e.g., for public organizations, see Mosher 1968; Lim 2006; Meier and O’Toole 2006; Choi and Rainey 2010; Pitts 2005; Pitts et al. 2010; Sabharwal 2014; for private organizations, see Cox and Blake 1991; Milliken and Martins 1996; Williams and O’Reilly 1998; Pelled, Eisenhardt, and Xin 1999). Furthermore, scholars acknowledge that when minority public administrators are more likely to advocate for the interests of their co-ethnic groups (Mosher 1968; Lim 2006), representativeness may conflict with other values such as equity and equality in the public sector (Selden 1997; Meier and O’Toole 2006) as well as the fundamental values of democracy. The conflicting expectations regarding the effect of diversity on performance lead to the following hypothesis.

H2a: Workforce diversity will have an impact on governmental performance. 
Meanwhile, empirical evidence consistently substantiates the positive effect of diversity management on organizational performance. Diversity management is defined in a broad sense as "the commitment on the part of organizations to recruit, retain, reward, and promote a heterogeneous mix of productive, motivated, and committed workers” (Ivancevich and Gilbert 2000: 77). In recent years, policies and programs for diversity management have adopted a more active and broad-based approach, including mentoring opportunities, training programs, familyfriendly policies, and advocacy groups (Bozeman and Feeney 2009; Kellough and Naff 2004; Pitts, 2006, 2009; Pitts et al., 2010; Riccucci, 2002; Sabharwal 2014). The goal of diversity management through all these policies, programs, and practices is to decrease the potential negative effect of workforce diversity and increase its potential positive effect (Andersen and Moynihan 2016; Choi 2009, 2010; Choi and Rainey 2010; Oberfield 2014; Pitts 2009; Riccucci 2002). Moskos and Butler (1997) shows that the U.S. Army has been successful in closing the racial gap by supporting equal opportunity to black soldiers and using incentives and sanctions tied to the organizational mission.

However, organizational efforts on diversity management may not directly translate into improved performance and inclusive work environment, unless the efforts are supported by the top-level leadership (Von Bergen et al. 2002; Groeneveld and Verbeek 2012; Sabharwal 2014). Pitts (2006: 254) insightfully conceptualized three key components of diversity management and the associated mechanisms through which an organization's managerial responses to diversity function to shape organizational performance. These components are recruitment and outreach (through increased organizational heterogeneity and integration), building cultural awareness (through cultural synergy), and pragmatic management policy (through job satisfaction). Diversity management without these key components may bring about unintended negative effects such as reverse discrimination, demoralization, and reinforced stereotypes (Von Bergen et al. 2002). One hypothesis related to diversity management follows:

H2b: Organizational efforts on diversity management are positively related to governmental performance.

\section{Merit Principles and Diversity Management}

Our further question concerns whether the effect of merit principles on performance is moderated by workforce diversity and diversity management. The growing demand for diversity in the public sector has brought about a variety of normative controversies and managerial challenges. One of the concerns relates to fairness and equity in human resource management process (Woodard 2005). Beliefs arise that government's policy intervention aimed at promoting organizational diversity and representativeness, such as affirmative action and equal employment opportunity (EEO) programs, inevitably increases the categorization and different treatment of employees, and engender tensions with the core values of merit principles (Johns 2005; Kellough and Naff 2004; Malleson 2006; McGregor 1974; Lim 2004). For instance, accompanying the adoption of antidiscrimination laws are backlash reactions toward and devaluation of program beneficiaries and historically underrepresented employees, particularly women and people of color (e.g., lower hiring criteria, discounting of qualification, less competence, substandard performance) and gains by individuals of a protected class at the expense of other social members (e.g., reverse discrimination) (Gilbert, Stead, and Ivancevich 1999; Heilman, Block, and Lucas 1992; Summers 1991; Von Bergen, Soper, and Foster 2002). It implies a negative link between government's corrective measures for compensating for historical injustices and organizational performance, through undermining merit-based personnel systems.

Diversity, however, potentially can be compatible with merit principles in the broader context of human resource management. As Pfiffner (2000: 28) suggested, affirmative action and equal opportunity regulations are part of the merit system "to ensure that entry and promotion are based on merit rather than prejudice". More important, often neglected are the intrinsic distinction between diversity management and traditional, legalistic approaches to redressing workplace discrimination (e.g., affirmative action, EEO programs), in terms of rationale, goal, approaches to problems, and programmatic design (Kelly and Dobbin 1998). Contemporary civil service reforms also have sought to modernize public sector management and boost government productivity by broadening the talent base that has long been dominated by white males (Ink 2000: 46). As Pitts and Towne (2015: 374) observed, "managing for diversity meant managing for all differences, whether based in race, ethnicity, gender, education, or function". Fundamentally speaking, diversity management recognizes value in diversity and focuses on "making sure all groups of employees had what they needed in order to succeed at work". As opposed to remedial initiatives that are justified on legal, social, and moral grounds, diversity management is characterized by productivity, efficiency, and quality, which are key management goals of merit principles (Kellough and Naff 2004: 65). In terms of administrative responsibility in a democracy, merit principles hold public employees accountable by protecting them from external influences (Kettl 2015), and diversity management enhances responsiveness and representation among civil servants as a political and managerial strategy resulting from representative bureaucracy (Ospina 2001). 
In other words, all organizational members, not limited to target groups in antidiscrimination legal mandates, are beneficiaries of the strategic efforts to manage diversity, which are conducive to realizing employees' potential underlying their diverse backgrounds, advancing employees' overall skills and abilities, mitigating stigmatizing perceptions, reshaping organizational culture and work environment, generating "positive spillover effect in the workplace", and enhancing organizational problem-solving capacities and competitive advantage (Gilbert, Stead, and Ivancevich 1999, 64; Kidder et al. 2004; Pitts and Towne 2015; Thomas 1990; Von Bergen, Soper, and Foster 2002). As such, diversity management is inherently in alignment with the expectations of the conventional merit-based systems and with the mission of contemporary performance-based reforms (Kellough and Naff 2004), ultimately leading to the improvement of organizational performance. We thus anticipate that government agencies' diversity management efforts complement merit-based principles and practices to enhance organizational effectiveness. Accordingly, two hypotheses related to the relationship between merit principles, workforce diversity, and diversity management follow:

H3a: The effect of organizational compliance with merit principles on governmental performance is positively moderated by workforce diversity.

$H 3 b$ : The effect of organizational compliance with merit principles on governmental performance is positively moderated by diversity management efforts.

\section{Data and Methods}

With federal subagency ${ }^{1}$ as the unit of analysis, this study examines the relationship between merit principles, workforce diversity, diversity management, and organizational performance in 2006. To test the hypotheses, we extract and analyze information on organizational performance, employees' perception on personnel management policies and practices (i.e., merit principles and diversity management), and workforce diversity from the Program Assessment Rating Tool (PART), Federal Human Capital Survey (FHCS), and FedScope federal human resources datasets, respectively.

\section{Organizational Performance}

Unlike prior studies using self-reported survey, this study utilizes an archival performance indicator from the PART. The dependent variable, organizational performance, is measured with PART scores of programs administered by a given subagency. Implemented from 2004 through 2007, the PART was a program evaluation and administrative accountability system managed by the Office of Management and Budget (OMB) under the George W. Bush administration (for more details of the history of PART, see Dull 2006). During the period of implementation, over 1,000 federal programs (representing $98 \%$ of the federal budget) were assessed (Moynihan 2013). "PART itself was a survey instrument, developed by OMB staff with outside advice. The instrument asked 25 to 30 questions divided into four categories: program purpose and design, strategic planning, program management, and program results" (ibid: 501) ${ }^{2}$. Based on the evaluation by OMB budget examiners and agency officials, a numerical grade (from 0 to 100) was given to each dimension that carries a different weight (purpose and design: $20 \%$, planning: 10\%, management: $20 \%$, and results: $50 \%$ ). A final, weighted total score (from 0 to 100 ) was generated for a given program (Gilmour and Lewis 2006). PART scores have been broadly employed to represent the performance of federal agencies or programs (Gallo and Lewis 2012; Gilmour and Lewis 2006; Jung 2013, 2014; Lewis 2008a; Miller 2015). Given that program is PART's unit of analysis, we use an aggregate measure for the subagency analysis, by generating an averaged weighted total score from the evaluated programs for its supervising subagency. Using PART scores does not exempt us from the concerns about subjective evaluation frequently associated with perceptual survey measures, but it helps enhance measurement reliability and validity. Also, using data from multiple sources of different nature helps mitigate the issue of common source bias (Favero and Bullock 2015).

\footnotetext{
${ }^{1}$ A federal agency may be composed of several subagencies.

2 "The first section of questions asks whether a program's purpose is clear and whether it is well designed to achieve its objectives. The second section involves strategic planning, and weighs whether the agency establishes valid annual and long-term goals for its programs. The third section rates the management of an agency's program, including financial oversight and program improvement efforts. The fourth section of questions focuses on results that programs can report with accuracy and consistency" (archival ExpectMore.gov: https://georgewbushwhitehouse.archives.gov/omb/expectmore/part.html).
} 
This is an author-produced, peer-reviewed version of this article. The final, definitive version of this document can be found online at Public Personnel Management, published by SAGE. Copyright restrictions may apply. doi: 10.1177/0091026019848459

\section{Merit-Based Practices}

The FHCS captures employees' perception regarding agencies' human resource management policies and practices. The FHCS was initiated by the U.S. Office of Personnel Management (OPM) in 2002 and administered biennially prior to 2010. Since being renamed as the Federal Employee Viewpoint Survey (FEVS) in 2010, the survey has been conducted annually. Respondents of this stratified sampling survey series are "full-time and part-time, permanent, non-seasonal employees of Departments and/large agencies and the small/independent agencies that accept an invitation to participate in the survey" (U.S. OPM 2018a). Covering various key human resource topics such as personal work experiences, work unit, agency, supervisor, leadership, satisfaction, work/life, and demographics, the FHCS (or FEVS) is "representative of the entire federal executive branch workforce as well as of employees within individual agencies" to "gauge employee perceptions and attitudes about their jobs, working conditions, organizational policies, coworkers, leaders, and performance” (Fernandez, Resh, Moldogaziev, and Oberfield 2015: 382; see also U.S. OPM 2017: 1). Because of the stratified sampling approach, survey results are generalizable to the subagency or agency populations.

The 2006 FHCS has a sample size of 221,479 and a government-wide response rate of 57\% (U.S. OPM 2006). Using the survey-generated statistical weights, we first aggregate and average responses to each selected FHCS item (coded in a 5-point Likert scale, 1 as "strongly disagree" and 5 as "Strongly Agree") at the subagency level (for a similar analytical strategy, see Jung 2010; Oberfield 2014). We then use factor analysis to generate a factor score for the perceived efficacy of the organizational policy on human resource management ${ }^{3}$.

Federal agencies' merit-based practices are measured with employees' perception on a subagency's compliance with merit principles and its adoption of merit-based human resource management practices. Specifically, merit-based hiring, promotion, and civil service protection are assessed with three questions: (1) "My work unit is able to recruit people with the right skills", (2) "Promotions in my work unit are based on merit", and (3) "Arbitrary action, personal favoritism and coercion for partisan political purposes are not tolerated". Performance evaluation and appraisal practices are assessed with three questions: (1) "Pay raises depend on how well employees perform their jobs", (2) "Awards in my work unit depend on how well employees perform their jobs", and (3) "My performance appraisal is a fair reflection of my performance”. The Cronbach's $\alpha$ coefficient for the responses to these six questions is .929. Factor analysis generates a factor score with an eigenvalue of 4.456. A higher value indicates a higher level of perceived compliance with merit principles and efficacy of performance management in a given subagency.

\section{Workforce Diversity}

The information on federal workforce diversity is garnered from FedScope federal human resources data, the sources of which are the Central Personnel Data File and Enterprise Human Resources Integration-Statistical Data Mart managed by the OPM. This administrative dataset reports the number of federal civilian employees in terms of a broad range of characteristics, including race and ethnicity, gender, occupational category, length of service, educational level, and pay plan and grade (U.S. OPM 2018b).

This study focuses on two important dimensions of demographic diversity: race/ethnicity and gender. Research has reported that the impact of workforce diversity on organizational performance can be different, depending on the specific demographic characteristic. FedScope data define race/ethnicity in six categories: American Indian or Alaska Native, Asian, Black or African American, Hispanic or Latino, Native Hawaiian or other Pacific Islander, and White. Gender is defined in two categories: female and male. The analysis uses the Blau index ${ }^{4}$ to measure each dimension of workforce diversity. A higher value indicates that a given subagency is more diverse with respect to specified demographic characteristics.

\footnotetext{
3 "Factor analysis is used mostly for data reduction purposes: to get a small set of variables (preferably uncorrelated) from a large set of variables (most of which are correlated to each other); [or] to create indexes with variables that measure similar things (conceptually)" (Torres-Reyna 2010: 2). An eigenvalue represents the "total variance accounted by each factor. The sum of all eigenvalues = total number of variables. Kaiser criterion suggests to retain those factors with eigenvalues equal or higher than 1" (ibid: 3). The predicted common factor score has mean zero and standard deviation 1. Factor analysis has been widely used to generate measures for latent concepts based on survey questions.

${ }^{4}$ Diversity $=1-\Sigma P_{i}^{2}$, where $P_{i}$ is the proportion of group members in a particular category $i .0$ and 1 represents perfect homogeneity and heterogeneity, respectively.
} 
This is an author-produced, peer-reviewed version of this article. The final, definitive version of this document can be found online at Public Personnel Management, published by SAGE. Copyright restrictions may apply. doi: 10.1177/0091026019848459

\section{Diversity Management Efforts}

Akin to merit-based practices, a measure for organizational efforts for diversity management is developed from the FHCS (Choi 2009; Oberfield 2014). Three items include: (1) "Supervisors/team-leaders in my work unit are committed to a workforce representative of all segments of society”, (2) "Policies and programs promote diversity in the workplace (e.g., recruiting minorities and women, training in awareness of diversity issues, mentoring)”, and (3) “Managers/supervisors/team leaders work well with employees of different backgrounds”. The Cronbach's $\alpha$ coefficient for the responses to these three items is .914. Factor analysis generates a factor score with an eigenvalue of 2.561. A higher value indicates a higher level of perceived efficacy of diversity management efforts in a given subagency.

\section{Control Variables}

The empirical models include several factors that also exert influence on a public agency’s performance. Organizations that have sufficient resources are more likely to have better performance (Gallo and Lewis 2012; Jung 2013). Organizational resources are measured with two variables: the aggregated actual 2005 program budget (dollars in millions, in natural logarithm) and the number of employees. To consider the influence of different program feature on an agency's performance, we include the number of programs of different types: direct federal, credit, research and development, block/formula grant, competitive grant, capital assets and service acquisition, and regulatory (Gallo and Lewis 2012). Federal employees in agencies with science/technology or regulatory functions are more likely to evaluate favorably the organizations' leadership, management, and work climate, which eventually would bear on organizational performance (Lewis 2008a). The analysis thus includes two indicator variables representing whether a subagency's primary mission is science/technology and whether a subagency is engaged in regulatory activities.

Agencies with a higher level of professionalism should have better organizational performance. On one hand, "The proportion of professional employees in the agency is closely connected with autonomy in human resources. Professionals exercise influence through the application of their expertise by deciding crucial issues of society” (Lee and Whitford 2013: 692). On the other hand, agencies that are more professionalized are less politicized, which in turn introduces fewer interferences in organizations' functioning and management (Lewis 2008a). The analysis controls for the effect of professionalism with the percent of employees in the professional category (in FedScope data, employee occupational categories include professional, administrative, clerical, technical, blue-collar, and unknown).

Lastly, two agency characteristics are included. An indicator variable is used to represent whether a subagency is an independent commission, which usually is subject to less political control than agencies headed by a single administrator (Canes-Wrone, Howell, and Lewis 2007). The other indicator variable measures whether a subagency’s ideology is "statistically distinguishable in a liberal direction from 0" (Lewis 2008b). "Since PART scores are generated by a Republican Administration, programs in liberal agencies will get systematically lower grades if the grades are politicized” (Gallo and Lewis 2012: 228). Data on agencies’ primary mission, commission status, and ideology are collected from Lewis (2008b).

\section{Estimating Models}

We use the ordinary least squares (OLS) regression model to estimate the effects of the predictor variables on federal agencies’ performance, with standard errors clustered at the subagency level. The final sample size is 88 (or 87 , depending on the model), for subagencies that have valid information on both the dependent and predictor variables (agencies and subagencies listed in appendix). To evaluate the moderating effects of workforce diversity and diversity management efforts on the impact of merit-based practices on agency performance (H3a and 3b), the analysis uses interaction terms between these three focal variables.

\section{Results}

Descriptive statistics are summarized in Table 1. In 2006, the mean of the average total PART scores of programs at the subagency level is 70.526 (minimum: 42.625, maximum: 93.464). The correlation matrix for the continuous predictor variables is reported in Table 2. Table 3 presents the effects of the predictor variables. Specially, Model 1 examines the independent effect of employees' perceptions of merit-based practices. Models 2 and 3 assess the effects 
This is an author-produced, peer-reviewed version of this article. The final, definitive version of this document can be found online at Public Personnel Management, published by SAGE. Copyright restrictions may apply. doi: 10.1177/0091026019848459

of workforce diversity and diversity management efforts. Models 4 and 5 comprehensively evaluate the interactive effects of two sets of organizational management efforts and workforce diversity on the performance of federal agencies.

[Tables 1 and 2 about Here]

As Model 1 shows, the effective implementation of merit-based policies is conducive to organizational performance. Holding other variables constant, a one-unit increase in merit-based efficacy score is associated with an increase of approximately 4.688 points in a subagency's PART score. Only one control variable is statistically significant. A subagency that administers a large number of research and development programs has a higher PART score. To our surprise, neither dimension of demographic diversity (i.e., race/ethnicity, gender) is statistically significant (Model 2). Two control variables have explanatory strength in accounting for organizational performance. Akin to Model 1, the number of research and development programs is positively associated with a subagency's performance. By contrast, management of a large number of block/formula grant programs is likely to dampen organizational performance. Model 3 simultaneously evaluates the independent effects of workforce diversity and diversity management efforts. Diversity management efforts remain statistically significant. With other factors being the same, a one-unit increase in employees' perceived efficacy of diversity management efforts is related to an increase in the PART score by 5.2 points in a given subagency. The number of research and development programs still has a positive effect, whereas the size of competitive grant programs has a negative effect.

\section{[Table 3 about Here]}

Model 4 displays the relationship between organizational workforce diversity and merit principles. The effect of meritbased practices on organizational performance is moderated by gender diversity, as the interaction term between these two variables is statistically significant in the positive direction. As the magnitude and significance of the effect of merit-based policies vary across the conditional values of gender diversity, the results are interpreted in terms of the marginal effect based on the post-estimation analysis. The conditional marginal effect of the perceived efficacy of merit-based policies increases as a function of gender diversity (Figure 1, see Mitchell 2012: 135). When the score of gender diversity is .447 (at the $25^{\text {th }}$ percentile), the marginal effect of merit-based practices becomes statistically significant. At this level, a one-unit increase in the perceived efficacy of organizational merit-based practices is associated with an increase of 3.647 points in the PART grade. By contrast, when an agency has a score of .497 (at the $95^{\text {th }}$ percentile) in gender diversity, its performance grade increases by 7.69 points, corresponding to a one-unit increase in the perceived effectiveness of organizational merit-based policies. It should also be noted that when an agency has a very low level of gender diversity (e.g., below a score of .397), the marginal effect of merit-based policies is negative. In a subagency where employees perceive merit-based policies as effective, the predicted PART score is higher if the organization also has a more diverse workforce in terms of gender (Figure 2).

[Figures 1 and 2 about Here]

Model 5 assesses the interactive effect of diversity management efforts and merit-based practices. Like Model 4, the interaction variable is statistically significant in the positive direction. The estimates of the effect of merit-based practices increase as a function of diversity management efficacy (Figure 3). Yet the marginal effect of the perceived efficacy of merit-based policies is statistically significant only in organizations with the highest level of the perceived effectiveness of diversity management efforts. For instance, when the score of diversity management efficacy is 2.264 (above the $95^{\text {th }}$ percentile), a one-unit increase in organizations' merit-based practices is correlated with a 4.717-point increase in the PART grade. At the high end of diversity management efforts, as employees recognize merit-based policies as more effective, the predicted PART score increases (Figure 4). For instance, in a subagency that has a score of 1.459 for the perceived effectiveness of merit-based policies, the predicted PART score is 83.28. By contrast, if merit-based practices are less effective (e.g., a score of -1.644), the subagency has a lower predicted PART score (e.g., 70.103).

\section{[Figures 3 and 4 about Here]}

Models 1, 2, 3, and 5 do not suggest the problem of multicollinearity, but Model 4 does indicate this issue. Yet we choose to keep the concerned variables in the model, as the estimation of coefficients is unbiased and dropping the data would cause specification error. Considering the multicollinearity problem, we are unable to reject the null hypothesis in our analysis, even though the effect may exist in the population (Gujarati 2002). 


\section{Discussion and Conclusion}

This study aims to explore the relationship between merit-based practices, workforce diversity, diversity management efforts, and government performance. Alongside echoing the calls for a continued understanding of the role of merit principles in shaping public agencies’ performance, it sheds light on the complex relationship between merit-based policies and managing for diversity, both of which are key components of human resource management in the public sector. The study contributes to the literature of public management by focusing on the differential effects of workforce diversity and diversity management on government performance, as well as their dynamics with government's meritbased practices. To test the hypotheses, this study analyzes three different datasets using weights and weighted averages, with federal subagency as the unit of analysis. This research design allows us to avoid problems associated with relying on information from one source and to examine government performance measured with objective/archival data instead of subjective/perceptual survey data.

The findings suggest a clear pattern consistent with our expectations and point to the important topics for future research. Overall, merit-based practices and diversity management efforts have independent positive impacts on the performance of federal agencies. However, there is no significant independent effect of workforce diversity in terms of gender or race/ethnicity. The results imply the possibility that the twofold effects of diversity cancel out its impact on performance. Considering the competing arguments on the effect of diversity, the null finding is not uncommon, as suggested by previous studies. Moreover, the effect of merit-based practices on organizational performance is reinforced by gender diversity and diversity management. The positive effect of merit-based practices on agency performance is statistically significant at the highest end of diversity management efforts. The results largely comport with the public management literature regarding the vital role of managers in shaping organizational performance (O’Toole and Meier 1999). The complementary relationship between merit-based practices, workforce diversity (gender specifically), and diversity management efforts implies the importance of adopting managerial strategies and tactics that further achieve workforce demographic representation, bolster the benefits of diversity, and promote merit principles in the public sector.

There is a reason for caution in understanding our findings, however, given that this study does not allow for an examination of several relevant factors identified in prior research, such as managerial discretion, policy congruence, and policy areas salient to minorities (e.g., Keiser et al. 2002; Wilkins and Keiser 2006). For instance, organizations with greater competence are more likely to have a higher level of performance. Furthermore, we acknowledge that the latent factors of merit-based practices and diversity management may not be significantly different from some of the generic concepts such as trust in management. The measurement problem, however, may not be resolved by using different questionnaire items for each variable in the same dataset. Two variables in the interaction term (i.e., meritbased practices and gender diversity) were highly correlated in Model 4, making it difficult to isolate the individual effect of the independent variables.

In addition to the possibility of omitting certain variables, the present study has several noteworthy limitations, raising avenues for future research on the performance of public organizations. First, using cross-sectional data without time dimension limits our capacity of exploring the causal relationship between the dependent variable and the focal independent variables. Data unavailability for the key program- and subagency-level variables is a practical reason for us to examine the relationship between organizational performance, merit-based practices, and diversity management efforts in a single year (i.e., 2006). As such, this practice does not consider the potential effect of temporal factors on organizational effectiveness; also the cross-sectional feature of the present study does not allow for causal inferences.

Lastly, the current literature have identified a variety of elements of merit principles and practices, this study only uses one composite measure from different questions in the FHCS, as factor analysis points to one underlying concept. This may be related to the limitation of using survey data with a selected set of questions and the assumptions regarding the key elements of merit principles. Further research may uncover additional aspects of merit-based practices that may be in accord or conflict with each other, thus reinforcing or confounding their causal connections with governmental performance. 


\section{References}

Andersen, S. C. and D. P. Moynihan (2016). "How Leaders Respond to Diversity: The Moderating Role of Organizational Culture on Performance Information Use.” Journal of Public Administration Research and Theory 26(3): 448-460.

Andrews, R., Boyne, A. G., Meier, K. J., O’Toole, L. J., \& Walker, R. M. (2005). "Representative bureaucracy, organizational strategy, and public service performance: An empirical analysis of English local government.” Journal of Public Administration Research and Theory 15: 489-504.

Bozeman, B. and M. K. Feeney. (2009). "Public management mentoring a three-tier model.” Review of Public Personnel Administration 29(2): 134-157.

Brook, D. A (2000). “Merit and the Civil Service Reform Act.” In J. P. Pfiffner, and D. A. Brook ed., The Future of Merit: Twenty Years after the Civil Service Reform Act. Washington, DC: The Woodrow Wilson Center Press. 1-11.

Canes-Wrone, B., W. G. Howell, D. E. Lewis. (2007). “Toward a Broader Understanding of Presidential Power: A reevaluation of the two presidencies thesis.” Journal of Politics 69(1): 1-16.

Choi, S. (2009). "Diversity in the US federal government: Diversity management and employee turnover in federal agencies.” Journal of Public Administration Research and Theory, 19, 603-630.

Choi, S. and H. G. Rainey. (2010). "Managing Diversity in U.S. Federal Agencies: Effects of diversity and diversity management on employee perceptions of organizational performance.” Public Administration Review 70: 109-21.

Cox, T. H. and S. Blake. (1991). "Managing Cultural Diversity: Implications for organizational competitiveness.” Academy of Management Executive 5(3): 45-56.

Dull, M. (2006). "Why PART? The Institutional Politics of Presidential Budget Reform.” Journal of Public Administration Research and Theory 16(2): 187-215.

Favero, N. and J. B. Bullock. (2015). "How (Not) to Solve the Problem: An Evaluation of Scholarly Responses to Common Source Bias.” Journal of Public Administration Research and Theory 25(1): 285-308.

Fernandez, S., W. G. Resh, T. Moldogaziev, and Z. W. Oberfield. (2015). “Assessing the Past and Promise of the Federal Employee Viewpoint Survey for Public Management Research: A Research Synthesis.” Public Administration Review 75(3): 382-394.

Gallo, N. and D. E. Lewis (2012). “The Consequences of Presidential Patronage for Federal Agency Performance.” Journal of Public Administration Research and Theory 22(2): 219-243.

Gerrish, E. (2016). "The Impact of Performance Management on Performance in Public Organizations: A MetaAnalysis.” Public Administration Review 76(1): 48-66.

Gilbert, J, A., B. A. Stead, and J. M. Ivancevich (1999). “Diversity Management: A New Organizational Paradigm.” Journal of Business Ethics 21(1): 61-76.

Gilmore, J. B. a. D. E. L. (2006). "Does Performance Budgeting Work? An Examination of OMB's PART Scores." Public Administration Review 66(5): 742 752.

Green, R., Forbis, R., Golden, A., Nelson, S. L., \& Robinson, J. (2006). “On the ethics of at-will employment relations in the public sector.” Public Integrity 8(4): 305-327.

Groeneveld, S. and S. Van de Walle. (2010). “A contingency approach to representative bureaucracy: power, equal opportunities and diversity.” International Review of Administrative Sciences 76(2): 239-258.

Groeneveld, S. and S. Verbeek. (2012). "Diversity policies in public and private sector organizations: An empirical comparison of incidence and effectiveness.” Review of Public Personnel Administration 32(4): 353-381.

Gujarati, D. N. (2002). Basic Econometrics. ${ }^{\text {th }}$ Edition. McGraw-Hill.

Heilman, M. E., Block, C. J., and Lucas, J. A. (1992). "Presumed Incompetent? Stigmatization and Affirmative Action Efforts.” Journal of Applied Psychology 77(4): 536-544.

Huselid, M. A. (1995). “The impact of human resource management practices on turnover, productivity, and corporate financial performance.” Academy of Management Journal 38(3): 635-672.

Ingraham, P. W. (2006). “Building Bridges over Troubled Waters: Merit as a Guide.” Public Administration Review 66: 486-495.

Ingraham, P. W., S. C. Selden, and D. P. Moynihan. (2000). "People and performance: Challenges for the future of the public service-The report of the Wye River conference.” Public Administration Review 60: 54-60.

Ink, D. (2000). “What was behind the 1978 civil service reform?” In J. P. Pfiffner, and D. A. Brook ed., The Future of Merit: Twenty Years after the Civil Service Reform Act. Washington, DC: The Woodrow Wilson Center Press. 39-56. 
This is an author-produced, peer-reviewed version of this article. The final, definitive version of this document can be found online at Public Personnel Management, published by SAGE. Copyright restrictions may apply. doi: 10.1177/0091026019848459

Ivancevich, J. M., \& Gilbert, J. A. (2000). “Diversity Management: Time for a New Approach.” Public Personnel Management 29(1): 75-92.

Jehn, K. A., Northcraft, G. B., \& Neale, M. A. (1999). "Why some differences make a difference: A field study of diversity, conflict, and performance in workgroups.” Administrative Science Quarterly 44: 741-763.

Johns, N. (2005). "Positive action and the problem of merit: employment policies in the National Health Service." Critical Social Policy 25(2): 139-163.

Johnson, T. (2015). “Service after Serving: Does Veterans' Preference Diminish the Quality of the US Federal Service?” Journal of Public Administration Research and Theory 25(3): 669-696.

Jung, C. S. (2010). "Predicting Organizational Actual Turnover Rates in the U.S. Federal Government.” International Public Management Journal 13(3): 297-317.

(2013). "Navigating a Rough Terrain of Public Management: Examining the Relationship between Organizational Size and Effectiveness." Journal of Public Administration Research and Theory 23(3): 663686.

Keiser, L. R., V. M. Wilkins, K. J. Meier, C. A. Holland. (2002). "Lipstick and Logarithms: Gender, Institutional Context, and Representative Bureaucracy." The American Political Science Review 96(3): 553-564.

Kellough, J. E. and H. Lu (1993). "The Paradox of Merit Pay in the Public Sector: Persistence of a Problematic Procedure.” Review of Public Personnel Administration 13(2): 45-64.

Kellough, J. E., and K. C. Naff (2004). "Responding to a Wake-up Call: An Examination of Federal Agency Diversity Management Programs.” Administration \& Society 36(1) 62-90.

Kellough, J. E. and L. G. Nigro (2006). "Dramatic Reform in the Public Service: At-Will Employment and the Creation of a New Public Workforce.” Journal of Public Administration Research and Theory 16(3): 447466.

Kelly, E., and F. Dobbin (1998). "How Affirmative Action Became Diversity Management: Employer Response to Antidiscrimination Law, 1961 to 1996.” American Behavioral Scientist 41(7) 960-984.

Kettl, D. F. (2015). “The Merit Principle in Crisis.” Governance: An International Journal of Policy, Administration, and Institutions 28(4): 421-424.

Kidder, D. L., M. J. Lankau, D. C. Mason, K. A. Mollica, and R. A. Friedman (2004) "Backlash Toward Diversity Initiatives: Examining the Impact of Diversity Program Justification, Personal and Group Outcomes.” International Journal of Conflict Management 15(1): 77-102.

Kranz, H. (1974). “Are Merit and Equity Compatible?” Public Administration Review 34: 434-40.

Krause, G. A., D. E. Lewis, and J. W. Douglas (2006). "Political Appointments, Civil Service Systems, and Bureaucratic Competence: Organizational Balancing and Executive Branch Revenue Forecasts in the American States." American Journal of Political Science 50(3): 770-787.

Lee, S.-Y., and A. B. Whitford (2013) "Assessing the Effects of Organizational Resources on Public Agency Performance: Evidence from the US Federal Government.” Journal of Public Administration Research and Theory 23(3): 687-712.

Lewis, D. E. (2008a). The Politics of Presidential Appointments: Political Control and Bureaucratic Performance. Princeton, NJ: Princeton University Press.

(2008b). Data and Codebook on "The Politics of Presidential Appointments: Political Control and Bureaucratic Performance.” https://my.vanderbilt.edu/davidlewis/data/

(2013). "The Impact of Veterans' Preference on the Composition and Quality of the Federal Civil Service.” Journal of Public Administration Research and Theory 23: 247-65.

Lim, H.-H. (2006). "Representative Bureaucracy: Rethinking Substantive Effects and Active Representation.” Public Administration Review 66(2): 193-204.

Malleson, K. (2006). "Rethinking the Merit Principle in Judicial Selection.” Journal of Law \& Society 33(1): 126140.

Maranto, R. (1998). "Thinking the unthinkable in public administration: A case for spoils in the federal bureaucracy.” Administration \& Society 29(6): 623-642.

McCrudden, C. (1998). “Merit Principles.” Oxford Journal of Legal Studies 18(4): 543-579.

McGregor, E. B. J. (1974). "Social Equity and the Public Service.” Public Administration Review 34(1): 18-29.

Meier, K. J., and L. J. O’Toole, Jr. (2006). Bureaucracy in a democratic state: A governance perspective. Johns Hopkins University Press.

Miller, S. M. (2015). “The Relationship Between Short-Term Political Appointments and Bureaucratic Performance: The Case of Recess Appointments in the United States.” Journal of Public Administration Research and Theory 25(3): 777-796. 
This is an author-produced, peer-reviewed version of this article. The final, definitive version of this document can be found online at Public Personnel Management, published by SAGE. Copyright restrictions may apply. doi: 10.1177/0091026019848459

Milliken, F. J. and L. L. Martins (1996). "Searching for Common Threads: Understanding the Multiple Effects of Diversity in Organizational Groups.” Academy of Management Review 21(2): 402-433.

Mitchell, M. N. (2012). A Visual Guide to Stata Graphics. Third Edition. College Station, TX: Stata Press.

Mosher, F. C. (1968). Democracy and the Public Service. New York: Oxford University Press.

Moskos, C. C., and J. S. Butler. (1997). All That We Can Be: Black Leadership and Racial Integration the Army Way. Basic Books.

Moynihan, D.P. (2013). “Advancing the Empirical Study of Performance Management: What We Learned From the Program Assessment Rating Tool.” The American Review of Public Administration 43(5): 499-517.

Naff, K. C., and C. Kellough. (2003). "Ensuring employment equity: Are federal diversity programs making a difference?” International Journal of Public Administration, 26, 1307-1336.

Oberfield, Z. W. (2014). "Accounting for Time: Comparing Temporal and Atemporal Analyses of the Business Case for Diversity Management.” Public Administration Review 74(6): 777-789.

Ogrysko, N. (2016). "Merit system principles are an asset, not liability in marketing federal careers, OPM says." Federal News Radio, November 30, 2016.

Ospina, S. (2001). “Managing Diversity in Civil Service: A conceptual framework for public organizations.” In Managing Diversity in the Civil Service, 11-29. Amsterdam: IOS Press.

O'Toole, L. J. Jr., and K. J. Meier. (1999). "Modeling the Impact of Public Management: Implications of Structural Context.” Journal of Public Administration Research and Theory, 9(4): 505-526.

O'Rourke, M. R. (1993). "Challenges to Performance Appraisals of Federal Employees Under the Civil Service Reform Act of 1978.” SDL Rev. 38: 341-358.

Pelled, L. P., K. M. Eisenhardt, and K. R. Xin. (1999). "Exploring the Black Box: An Analysis of Work Group Diversity, Conflict, and Performance.” Administrative Science Quarterly 44(1): 1-28.

Pearce, J. L. and J. L. Perry (1983). “Federal Merit Pay: A Longitudinal Analysis.” Public Administration Review 43(4): 315-325.

Perry, J. L. (1986). "Merit Pay in the Public sector: The case for a failure of theory.” Review of Public Personnel Administration 7(1): 57-69.

Pfiffner, P. J., and Brook, D. A. (2000). The Future of Merit: Twenty Years After the Civil Service Reform Act. Washington D.C., Woodrow Wilson Center Press; Baltimore, Johns Hopkins University.

Pfiffner, P. J. (2000). “Government legitimacy and the role of the civil service.” In J. P. Pfiffner, and D. A. Brook ed., The Future of Merit: Twenty Years after the Civil Service Reform Act. Washington, DC: The Woodrow Wilson Center Press. 15-38.

Pitkin, H. F. (1967). The Concept of Representation. Berkeley: University of California Press.

Pitts, D. W. (2005). "Diversity, Representation, and Performance: Evidence about race and ethnicity in public organizations." Journal of Public Administration Research and Theory 15: 615-31.

(2006). “Modeling the Impact of Diversity Management.” Review of Public Personnel Administration 26(3): 245-268.

(2009). “Diversity Management, Job Satisfaction, and Performance: Evidence from U.S. Federal Agencies.” Public Administration Review 69(2): 328-338.

Pitts, D. W., A. K. Hicklin, D. P. Hawes, and E. Melton. (2010). "What Drives the Implementation of Diversity Management Programs? Evidence from public organizations.” Journal of Public Administration Research and Theory 20: 867-86.

Pitts, D. W., and S. E. Towne (2015). "Realizing the Promise of Diversity.” In J. L. Perry, and R. K. Christensen ed., Handbook of Public Administration. $3^{\text {rd }}$ Edition. San Francisco: Jossey-Bass. 366-381.

Riccucci, N. M. (2002). Managing Diversity in Public Sector Workforces. Boulder , CO: Westview Press.

Ruhil, A. V. S. and P. J. Camões (2003). "What Lies Beneath: The Political Roots of State Merit Systems.” Journal of Public Administration Research and Theory 13(1): 27-42.

Sabharwal, M. (2014). "Is Diversity Management Sufficient? Organizational Inclusion to Further Performance." Public Personnel Management 43(2): 197-217.

Selden, S. C. and F. Selden (2001). "Rethinking Diversity in Public Organizations for the 21st Century: Moving toward a Multicultural Model.” Administration \& Society 33(3): 303-329.

Summers, R. J. (1991). "The Influence of Affirmative Action on Perceptions of a Beneficiary's Qualifications.” Journal of Applied Social Psychology 21(15): 1265-1276.

Thomas, R. R. (1990). "From Affirmative Action to Affirming Diversity.” Harvard Business Review 68(2): 107117.

Thomas, D. A. and R. J. Ely. (1996). "Making Differences Matter: A New Paradigm for Managing Diversity” Harvard Business Review. Sept/Oct pp. 79-90. 
This is an author-produced, peer-reviewed version of this article. The final, definitive version of this document can be found online at Public Personnel Management, published by SAGE. Copyright restrictions may apply. doi: 10.1177/0091026019848459

Torres-Reyna, O. (2010). Getting Started in Factor Analysis (Using Stata 10). Princeton, NJ: Princeton University.

Tsui, A., Egan, T., \& O’Reilly, C. (1992). "Being different: Relational demography and organizational attachment.” Administrative Science Quarterly 37: 549-579.

U.S. Office of Personnel Management (OPM) (2006). Results from the 2006 Federal Human Capital Survey. Washington, DC: Author. (2017). 2017 Federal Employee Viewpoint Survey Technical Report. Washington, DC: Author. (2018a). About the Federal Employee Viewpoint Survey. Available at https://www.opm.gov/fevs/about/. (2018b). FedScope Federal Human Resources Data. Available at https://www.fedscope.opm.gov/index.asp.

Von Bergen, C.W., B. Soper, and T. Foster (2002). "Unintended Negative Effects of Diversity Management.” Public Personnel Management 31(2): 239-251.

Watson, W., Kumar, K., \& Michaelson, L. (1993). "Cultural diversity’s impact on interaction process and performance: Comparing homogeneous and diverse task groups.” Academy of Management Journal 36: 590-602.

Weibel, A., K. Rost, \& M. Osterloh. (2010). "Pay for Performance in the Public Sector? Benefits and (Hidden) Costs.” Journal of Public Administration Research and Theory 20(2): 387-412.

Wilkins, V. M. and L. R. Keiser. (2006). "Linking Passive and Active Representation by Gender: The Case of Child Support Agencies.” Journal of Public Administration Research and Theory 16: 87-102.

Williams, K. Y., and C. A. O’Reilly III (1998). "Demography and Diversity in Organizations: A review of 40 years of research.” Research in Organizational Behavior 20: 77-140.

Woodard, C. A. (2005). "Merit by Any Other Name—Refraining the Civil Service First Principle.” Public Administration Review 65(1): 109-116.

\section{Table 1. Descriptive Statistics}

\begin{tabular}{lccccc}
\hline & Mean & Std. Dev. & Min & Max & $N$ \\
\cline { 2 - 6 } PART score (0-100) & 70.526 & 12.506 & 42.625 & 93.464 & 89 \\
Merit-based practices (factor score) & 0 & 1 & -2.457 & 3.078 & 89 \\
Diversity management efforts (factor score) & $1.61 \mathrm{E}-09$ & 1 & -2.736 & 3.025 & 89 \\
Gender diversity (0-1) & 0.466 & 0.034 & 0.367 & 0.500 & 88 \\
Race diversity (0-1) & 0.450 & 0.120 & 0.139 & 0.662 & 87 \\
Actual 2005 program budget (millions) & 10143.2 & 39813 & 3 & 343866 & 89 \\
Direct federal program (number) & 1.708 & 2.752 & 0 & 19 & 89 \\
Credit program (number) & 0.146 & 0.490 & 0 & 3 & 89 \\
Research and development program (number) & 0.517 & 1.516 & 0 & 10 & 89 \\
Block/formula grant program (number) & 0.798 & 1.955 & 0 & 14 & 89 \\
Competitive grant program (number) & 1.169 & 2.731 & 0 & 16 & 89 \\
Capital assets/service acquisition program (number) & 0.404 & 1.145 & 0 & 8 & 89 \\
Regulatory program (number) & 0.427 & 0.796 & 0 & 5 & 89 \\
Science/technology agency (0,1) & 0.258 & 0.440 & 0 & 1 & 89 \\
Regulatory agency (0,1) & 0.337 & 0.475 & 0 & 1 & 89 \\
Professional employees (\%) & 25.394 & 20.609 & 0.709 & 77.986 & 88 \\
Employees (number) & 8857.14 & 15259.6 & 25 & 91340 & 88 \\
Commission (0,1) & 0.112 & 0.318 & 0 & 1 & 89 \\
Liberal agency (0,1) & 0.292 & 0.457 & 0 & 1 & 89 \\
\hline
\end{tabular}


This is an author-produced, peer-reviewed version of this article. The final, definitive version of this document can be found online at Public Personnel Management, published by SAGE. Copyright restrictions may apply. doi: 10.1177/0091026019848459

Table 2. Pairwise Correlations of the Predictor Variables

\begin{tabular}{|c|c|c|c|c|c|c|c|}
\hline & $\begin{array}{c}\text { Merit- } \\
\text { based } \\
\text { practices }\end{array}$ & $\begin{array}{c}\text { Diversity } \\
\text { management } \\
\text { efforts }\end{array}$ & $\begin{array}{l}\text { Gender } \\
\text { diversity }\end{array}$ & Race diversity & $\begin{array}{l}\text { Actual } \\
2005 \\
\text { program } \\
\text { budget }\end{array}$ & $\begin{array}{c}\text { Direct } \\
\text { federal } \\
\text { program }\end{array}$ & $\begin{array}{c}\text { Credit } \\
\text { program }\end{array}$ \\
\hline Merit-based practices & 1 & & & & & & \\
\hline Diversity management efforts & $0.8055^{*}$ & 1 & & & & & \\
\hline Gender diversity & $0.3021 *$ & 0.185 & 1 & & & & \\
\hline Race diversity & -0.1086 & -0.0954 & 0.1208 & 1 & & & \\
\hline Actual 2005 program budget & -0.0158 & -0.0053 & -0.1183 & 0.1313 & 1 & & \\
\hline Direct federal program & -0.0251 & 0.0081 & 0.0481 & -0.0256 & 0.0267 & 1 & \\
\hline Credit program & -0.1273 & 0.0012 & 0.1891 & 0.008 & -0.0455 & 0.0067 & 1 \\
\hline Research and development & 0.0944 & 0.0779 & -0.0226 & $-0.2148 *$ & -0.0425 & -0.1459 & -0.1029 \\
\hline Block/formula grant program & -0.145 & -0.1375 & -0.0423 & 0.1863 & 0.1463 & $0.2318 *$ & 0.0193 \\
\hline Competitive grant program & -0.0153 & -0.0223 & -0.0311 & 0.1337 & -0.0129 & 0.114 & -0.0611 \\
\hline Capital assets/service acquisition & -0.0214 & -0.0864 & -0.024 & -0.0738 & -0.0509 & 0.1172 & -0.0052 \\
\hline Regulatory program & 0.1627 & 0.149 & 0.0642 & $-0.211^{*}$ & -0.1188 & -0.098 & -0.1326 \\
\hline Professional employees & $0.2658 *$ & 0.1444 & $0.2201^{*}$ & -0.0782 & -0.0631 & -0.1629 & -0.1839 \\
\hline Total employees & -0.2 & -0.1167 & $-0.3083 *$ & 0.0694 & 0.1235 & $0.3526 *$ & -0.0885 \\
\hline
\end{tabular}

\begin{tabular}{|c|c|c|c|c|c|c|}
\hline & $\begin{array}{c}\text { Research and } \\
\text { development } \\
\text { program } \\
\end{array}$ & $\begin{array}{l}\text { Block/formula } \\
\text { grant program }\end{array}$ & $\begin{array}{l}\text { Competiti } \\
\text { ve grant } \\
\text { program }\end{array}$ & $\begin{array}{c}\text { Capital } \\
\text { assets/service } \\
\text { acquisition }\end{array}$ & $\begin{array}{c}\text { Regulatory } \\
\text { program }\end{array}$ & $\begin{array}{c}\text { Professional } \\
\text { employees }\end{array}$ \\
\hline Block/formula grant program & -0.0755 & 1 & & & & \\
\hline Competitive grant program & $0.3328 *$ & $0.564 *$ & 1 & & & \\
\hline Capital assets/service acquisition & $0.3364 *$ & 0.0369 & $0.2504 *$ & 1 & & \\
\hline Regulatory program & 0.041 & -0.1483 & -0.138 & -0.1043 & 1 & \\
\hline Professional employees & $0.3662 *$ & 0.0957 & 0.1392 & 0.0353 & 0.1785 & 1 \\
\hline Employees & -0.0205 & -0.1029 & -0.1065 & 0.0906 & 0.0073 & -0.1659 \\
\hline
\end{tabular}

$* p<0.05$ 
Table 3. The Estimates of the Effects of Predictors on Organizational Performance

Merit-based practices

Diversity management efforts

Gender diversity

Race diversity

Actual 2005 program budget

Direct federal program

Credit program

Research and development program

Block/formula grant program

Competitive grant program

Capital assets/service acquisition program

Regulatory program

Science/technology agency

Regulatory agency

Professional employees

Employees

Commission

Liberal agency

Constant

$N$

F Statistic

$\mathrm{R}^{2}$

\begin{tabular}{|c|c|c|c|c|c|}
\hline \multicolumn{2}{|c|}{ Model 1} & \multicolumn{2}{|c|}{ Model 2} & \multicolumn{2}{|c|}{ Model 3} \\
\hline Coef. & SE & Coef. & SE & Coef. & SE \\
\hline $4.688 * * *$ & 1.390 & --- & --- & --- & --- \\
\hline --- & --- & --- & --- & $5.202 * * *$ & 1.489 \\
\hline --- & --- & -15.567 & 47.896 & -39.171 & 45.542 \\
\hline--- & --- & 12.732 & 15.038 & 11.347 & 14.352 \\
\hline-0.238 & 0.663 & -0.686 & 0.828 & -0.827 & 0.796 \\
\hline 0.304 & 0.738 & 0.574 & 0.842 & 0.578 & 0.688 \\
\hline 0.564 & 1.643 & 0.187 & 1.967 & 0.435 & 1.730 \\
\hline $1.502 * * *$ & 0.519 & $1.804^{*}$ & 0.912 & $1.617 * *$ & 0.626 \\
\hline-1.103 & 0.817 & $-1.674^{*}$ & 0.884 & -1.056 & 0.792 \\
\hline-0.844 & 0.536 & -0.747 & 0.575 & $-1.003^{*}$ & 0.519 \\
\hline-0.991 & 0.914 & -0.781 & 1.019 & -0.488 & 0.863 \\
\hline-0.982 & 1.822 & -0.060 & 2.233 & -1.433 & 1.727 \\
\hline 1.857 & 2.837 & 1.101 & 3.101 & 2.266 & 2.948 \\
\hline-3.819 & 3.548 & -3.096 & 3.844 & -2.121 & 3.573 \\
\hline-0.022 & 0.082 & 0.047 & 0.074 & 0.014 & 0.082 \\
\hline -7E-05 & 7.1E-05 & -0.0001 & 9.5E-05 & $-1 E-04$ & 7.9E-05 \\
\hline 4.060 & 6.005 & 0.642 & 5.342 & 3.737 & 6.574 \\
\hline-0.983 & 3.338 & -0.908 & 3.841 & 0.525 & 3.774 \\
\hline 75.589† & 5.474 & $78.665 * * *$ & 23.362 & 90.777 & 22.249 \\
\hline \multicolumn{2}{|c|}{88} & \multicolumn{2}{|c|}{87} & \multicolumn{2}{|c|}{87} \\
\hline \multicolumn{2}{|c|}{ 4.33† } & \multicolumn{2}{|c|}{$1.6^{*}$} & \multicolumn{2}{|c|}{$3.46 \dagger$} \\
\hline \multicolumn{2}{|c|}{0.294} & \multicolumn{2}{|c|}{0.202} & \multicolumn{2}{|c|}{0.338} \\
\hline
\end{tabular}

Robust standard errors in the right column

${ }^{*} p<0.10$; ** $p<0.05$; *** $p<0.01 ; \dagger p<0.001$ 
This is an author-produced, peer-reviewed version of this article. The final, definitive version of this document can be found online at Public Personnel Management, published by SAGE. Copyright restrictions may apply. doi: 10.1177/0091026019848459

Table 3. The Estimates of the Effects of Predictors on Organizational Performance (Continued)

Merit-based practices

Diversity management efforts

Model $4 \ddagger \quad$ Model 5

Gender diversity

Race diversity

Merit-based practices $\times$ race diversity

Merit-based practices $\times$ gender diversity

\begin{tabular}{cccc}
\hline Coef. & SE & Coef. & SE \\
\hline-24.059 & 19.763 & 1.736 & 2.055 \\
--- & --- & $3.817 *$ & 2.244
\end{tabular}

Merit-based practices $\times$ diversity management efforts

$\begin{array}{cccc}8.639 & 13.636 & --- & --- \\ -17.994 & 58.745 & --- & --- \\ -18.701 & 11.579 & --- & --- \\ 80.855^{*} & 42.314 & --- & ---\end{array}$

Actual 2005 program budget

$\begin{array}{llll}--- & -- & 1.317^{*} & 0.707\end{array}$

Direct federal program

Credit program

Research and development program

Block/formula grant program

Competitive grant program

Capital assets/service acquisition program

$\begin{array}{llll}-0.415 & 0.770 & -0.480 & 0.679\end{array}$

$\begin{array}{llll}0.760 & 0.666 & 0.377 & 0.677\end{array}$

$\begin{array}{llll}2.034 & 1.793 & 0.260 & 1.750\end{array}$

Regulatory program

$\begin{array}{llll}1.809 * * & 0.632 & 1.268 * * & 0.559\end{array}$

$\begin{array}{llll}-1.211 & 0.838 & -0.896 & 0.786\end{array}$

Science/technology agency

$\begin{array}{llll}-1.015 * & 0.556 & -0.947 * & 0.545\end{array}$

$\begin{array}{llll}-0.878 & 0.930 & -0.728 & 0.930\end{array}$

Regulatory agency

$\begin{array}{llll}-1.312 & 2.115 & -1.823 & 1.527\end{array}$

Professional employees

$\begin{array}{llll}2.420 & 2.880 & 2.470 & 2.850\end{array}$

Employees

$\begin{array}{llll}-3.610 & 3.841 & -2.544 & 3.406\end{array}$

Commission

$\begin{array}{llll}0.018 & 0.085 & 0.004 & 0.084\end{array}$

Liberal agency

$-0.000 *$

7.5E-05

$-.0000$

7.3E-05

4.146

6.609

4.331

6.023

Constant

$-0.934$

3.713

$-0.499$

3.482

N

$78.943 * * * \quad 28.654$

$75.046 \dagger$

5.772

\begin{tabular}{llr} 
F Statistic & $3.68 \dagger$ & $4.05 \dagger$ \\
$\mathrm{R}^{2}$ & 0.358 & 0.345 \\
\hline
\end{tabular}

Robust standard errors in the right column

$* p<0.10 ; * * p<0.05 ; * * * p<0.01 ; \dagger p<0.001$

‡ The variables Merit-based practices and Gender diversity are highly correlated in Model 4. 
Figure 1. The Conditional Marginal Effects of Merit-Based Practices, Moderated by Gender Diversity

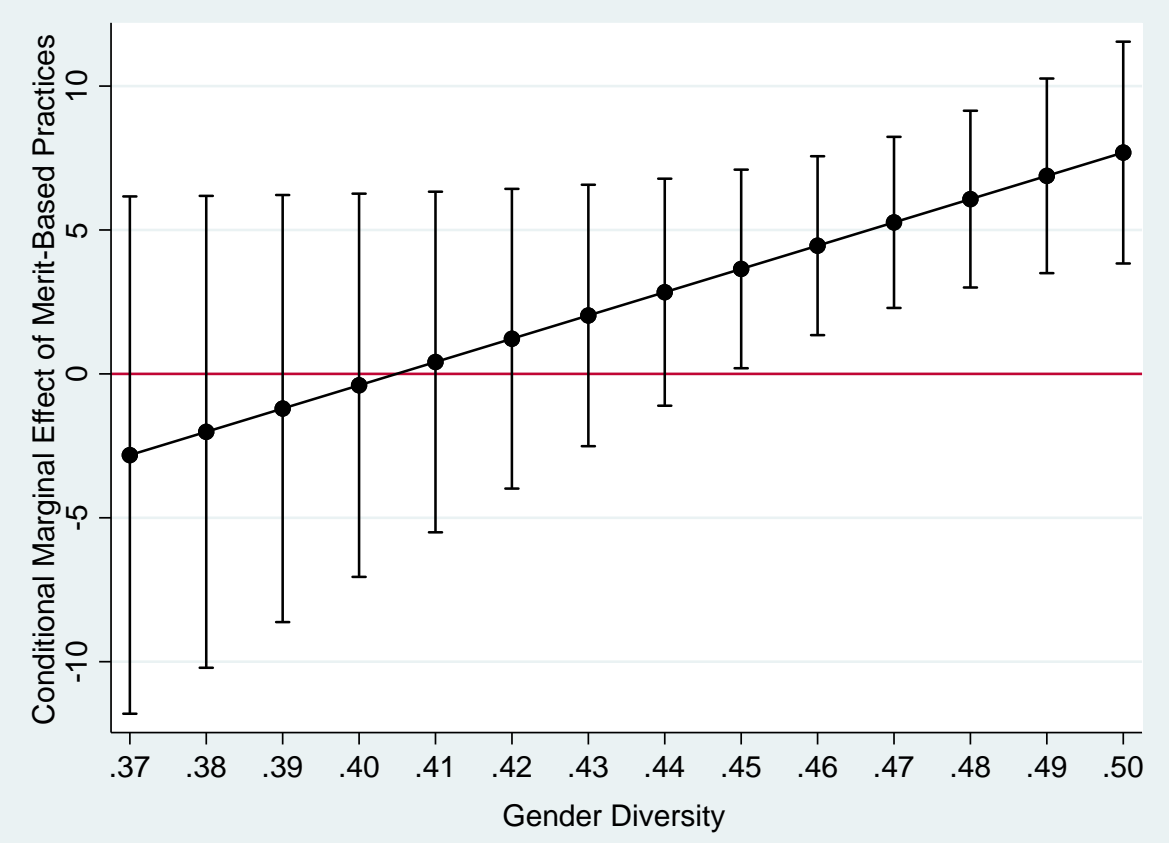

Figure 2. The Predicted Performance Scores, by Merit-Based Practices and Gender Diversity

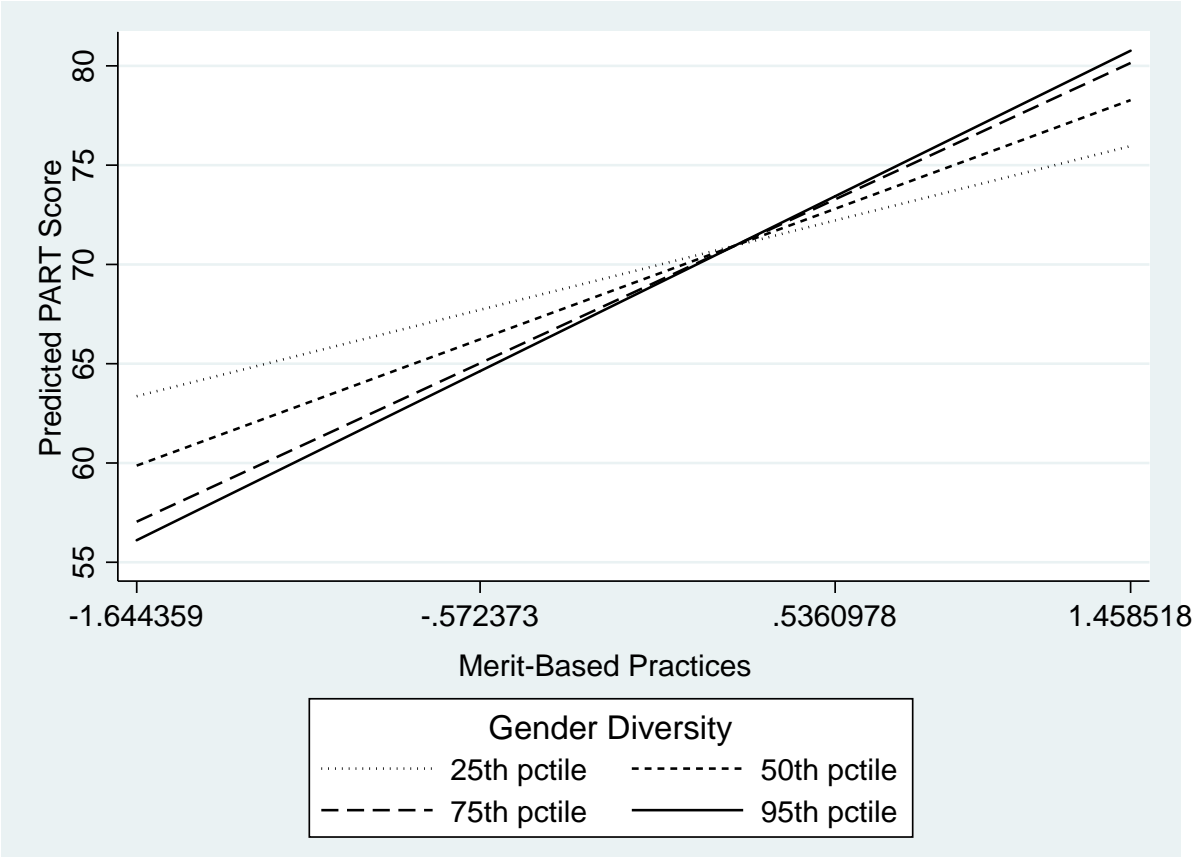


Figure 3. The Conditional Marginal Effects of Merit-Based Practices, Moderated by Diversity Management Efforts

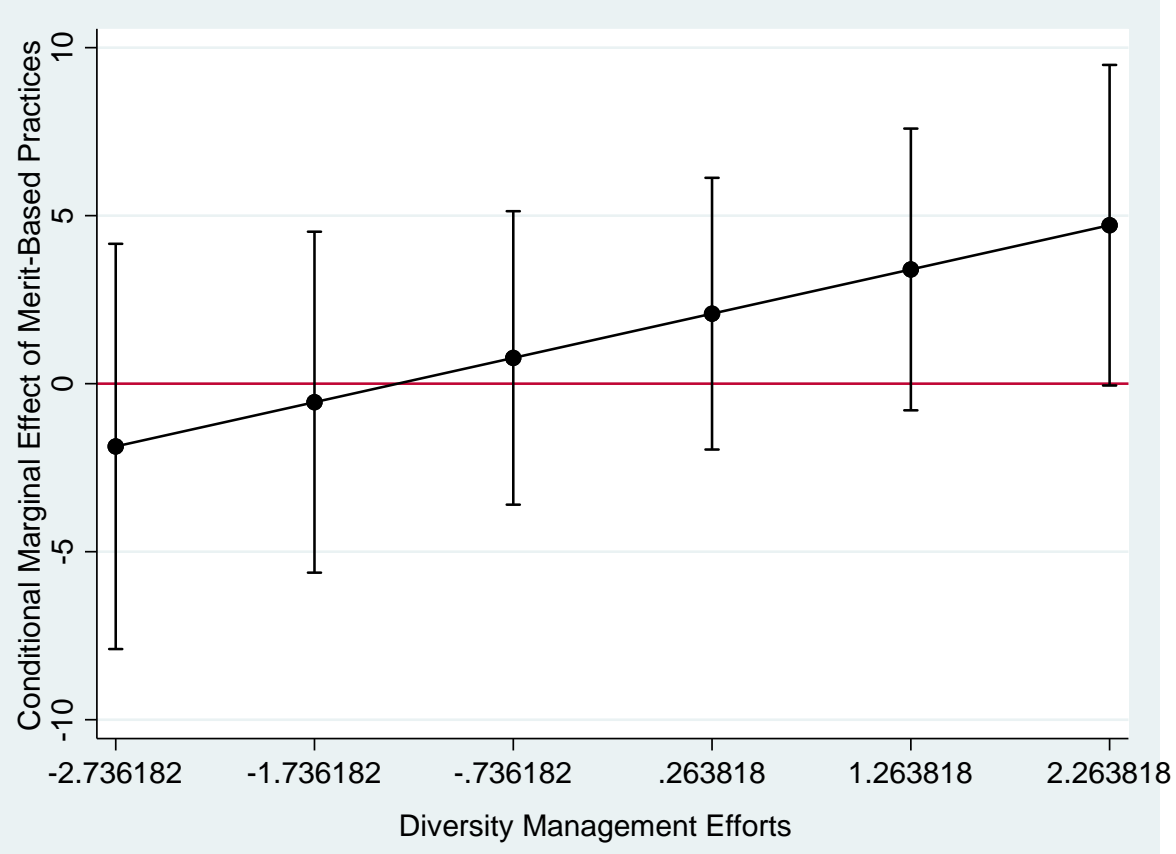

Figure 4. The Predicted Performance Scores, by Merit-Based Practices and Diversity Management Efforts

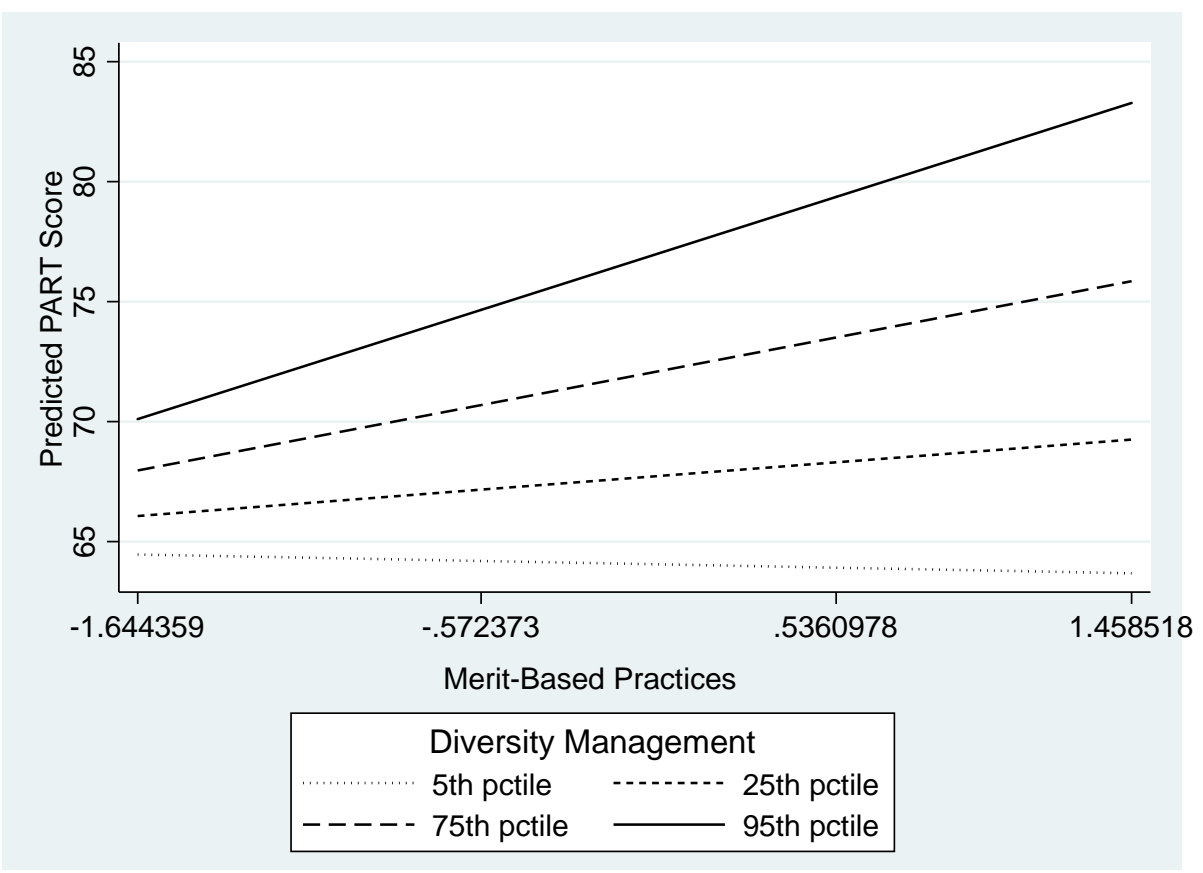


This is an author-produced, peer-reviewed version of this article. The final, definitive version of this document can be found online at Public Personnel Management, published by SAGE. Copyright restrictions may apply. doi: 10.1177/0091026019848459

\section{Appendix: Federal Agencies and Subagencies in This Study}

\begin{tabular}{|c|c|}
\hline Agency & Subagency \\
\hline Department of Agriculture & Agricultural Marketing Service \\
\hline Department of Agriculture & Agricultural Research Service \\
\hline Department of Agriculture & Rural Housing Service \\
\hline Department of Agriculture & Risk Management Agency \\
\hline Department of Agriculture & Foreign Agricultural Service \\
\hline Department of Agriculture & Forest Service \\
\hline Department of Agriculture & Natural Resources Conservation Service \\
\hline Department of Agriculture & National Agricultural Statistics Service \\
\hline Department of Agriculture & Food and Nutrition Service \\
\hline Department of Agriculture & Animal and Plant Health Inspection Service \\
\hline Department of Agriculture & Grain Inspection, Packers and Stockyards Administration \\
\hline Department of Agriculture & Food Safety and Inspection Service \\
\hline Department of Agriculture & Farm Service Agency \\
\hline United States Agency for International Development & United States Agency for International Development \\
\hline African Development Foundation & African Development Foundation \\
\hline Department of Commerce & National Oceanic and Atmospheric Administration \\
\hline Department of Commerce & International Trade Administration \\
\hline Department of Commerce & Patent and Trademark Office \\
\hline Department of Commerce & National Institute of Standards and Technology \\
\hline Department of Commerce & Bureau of the Census \\
\hline Commodity Futures Trading Commission & Commodity Futures Trading Commission \\
\hline National Credit Union Administration & National Credit Union Administration \\
\hline Department of Justice & Drug Enforcement Administration \\
\hline Department of Justice & Federal Bureau of Investigations \\
\hline Department of Justice & Bureau of Prisons/Federal Prison System \\
\hline Department of Justice & Office of Justice Programs \\
\hline Department of Justice & U.S. Marshals Service \\
\hline Department of Justice & Alcohol, Tobacco, Firearms, and Explosives \\
\hline Department of Labor & Employment Standards Administration \\
\hline Department of Labor & Employment and Training Administration \\
\hline Department of Labor & Bureau of Labor Statistics \\
\hline Department of Labor & Mine Safety and Health Administration \\
\hline Department of Labor & Employee Benefits Security Administration \\
\hline Department of Labor & Occupational Safety and Health Administration \\
\hline Export-Import Bank & Export-Import Bank \\
\hline Department of Education & Office of Special Education and Rehabilitative Services \\
\hline Department of Education & Federal Student Aid \\
\hline Department of Education & Office of Postsecondary Education \\
\hline Trade and Development Agency & Trade and Development Agency \\
\hline Department of Health and Human Services & Administration on Aging \\
\hline Department of Health and Human Services & Substance Abuse and Mental Health Services Administration \\
\hline Department of Health and Human Services & Agency for Healthcare Research and Quality \\
\hline Department of Health and Human Services & Health Resources and Services Administration \\
\hline Department of Health and Human Services & Food and Drug Administration \\
\hline Department of Health and Human Services & Indian Health Service \\
\hline Department of Health and Human Services & National Institutes of Health \\
\hline
\end{tabular}


This is an author-produced, peer-reviewed version of this article. The final, definitive version of this document can be found online at Public Personnel Management, published by SAGE. Copyright restrictions may apply. doi: 10.1177/0091026019848459

\begin{tabular}{|c|c|}
\hline Department of Health and Human Services & Centers for Disease Control and Prevention \\
\hline Department of Health and Human Services & Centers for Medicare and Medicaid Services \\
\hline Department of Health and Human Services & Administration for Children and Families \\
\hline Department of Homeland Security & Bureau of Citizenship and Immigration Services \\
\hline Department of Homeland Security & United States Coast Guard \\
\hline Department of Homeland Security & United States Secret Service \\
\hline Department of Homeland Security & Transportation Security Administration \\
\hline Department of Homeland Security & Bureau of Customs and Border Protection \\
\hline Department of Homeland Security & Federal Law Enforcement Training Center \\
\hline Department of Homeland Security & Federal Emergency Management Agency \\
\hline Department of Homeland Security & Office of the Under Secretary for Science and Technology \\
\hline Broadcasting Board of Governors & Broadcasting Board of Governors \\
\hline Inter-American Foundation & Inter-American Foundation \\
\hline Department of the Interior & Bureau of Land Management \\
\hline Department of the Interior & Bureau of Indian Affairs \\
\hline Department of the Interior & Bureau of Reclamation \\
\hline Department of the Interior & U.S. Geological Survey \\
\hline Department of the Interior & National Park Service \\
\hline Department of the Interior & U.S. Fish and Wildlife Service \\
\hline Department of the Interior & Office of Surface Mining, Reclamation and Enforcement \\
\hline Department of the Interior & Minerals Management Service \\
\hline Corporation for National and Community Service & Corporation for National and Community Service \\
\hline Federal Election Commission & Federal Election Commission \\
\hline National Science Foundation & National Science Foundation \\
\hline National Archives and Records Administration & National Archives and Records Administration \\
\hline Nuclear Regulatory Commission & Nuclear Regulatory Commission \\
\hline Peace Corps & Peace Corps \\
\hline Small Business Administration & Small Business Administration \\
\hline Securities and Exchange Commission & Securities and Exchange Commission \\
\hline Consumer Product Safety Commission & Consumer Product Safety Commission \\
\hline Department of State & Department of State \\
\hline Social Security Administration & Social Security Administration \\
\hline Department of Transportation & Federal Aviation Administration \\
\hline Department of Transportation & Federal Highway Administration \\
\hline Department of the Treasury & Office of Thrift Supervision \\
\hline Department of the Treasury & Alcohol and Tobacco Tax and Trade Bureau \\
\hline Department of the Treasury & Internal Revenue Service \\
\hline Department of the Treasury & Financial Management Service \\
\hline Department of the Treasury & Bureau of the Public Debt \\
\hline Department of the Treasury & United States Mint \\
\hline Department of the Treasury & Office of the Comptroller of Currency \\
\hline
\end{tabular}

